\title{
Olive oil polyphenol extract inhibits vegetative cells of Bacillus cereus isolated from raw milk
}

\author{
Peng Fei, ${ }^{1,2}$ Yunfeng $\mathrm{Xu}^{2}{ }^{2}$ Shengjuan Zhao, ${ }^{2}$ Shaoying Gong, ${ }^{1}$ and Ling Guo ${ }^{1 *}$ \\ ${ }^{1}$ Key Laboratory of Dairy Science, Ministry of Education, College of Food Science, Northeast Agricultural University, Harbin 150030, China \\ ${ }^{2}$ College of Food and Bioengineering, Henan University of Science and Technology, Luoyang 471023, China
}

\section{ABSTRACT}

This study was conducted to analyze the antibacterial effect of olive oil polyphenol extract (OOPE) against vegetative cells of Bacillus cereus isolated from raw milk and reveal the possible antibacterial mechanism. The diameter of inhibition zone, minimum inhibitory concentration, minimum bactericidal concentration, and survival counts of bacterial cells in sterile normal saline and pasteurized milk were used to evaluate the antibacterial activity of OOPE against $B$. cereus vegetative cells. The changes in intracellular ATP concentration, cell membrane potential, content of bacterial protein, and cell morphology were analyzed to reveal possible mechanisms of action. Our results showed the diameter of inhibition zone, minimum inhibitory concentration, and minimum bactericidal concentration of OOPE against $B$. cereus vegetative cells were $18.44 \pm 0.55 \mathrm{~mm}, 0.625 \mathrm{mg} / \mathrm{mL}$, and $1.25 \mathrm{mg} / \mathrm{mL}$, respectively. Bacillus cereus GF-1 vegetative cells were decreased to undetectable levels from about $8 \mathrm{log} \mathrm{cfu} /$ $\mathrm{mL}$ after treatments with $0.625 \mathrm{mg} / \mathrm{mL}$ of OOPE in normal saline at $30^{\circ} \mathrm{C}$ for $3 \mathrm{~h}$ and in pasteurized milk at $30^{\circ} \mathrm{C}$ for $10 \mathrm{~h}$. The antibacterial mechanisms of OOPE against $B$. cereus GF-1 vegetative cells may be due to the reduction of intracellular ATP concentrations, cell membrane depolarization, decrease of bacterial protein content, and leakage from cytoplasm. These findings illustrated that OOPE could be used to prevent the growth of contaminating $B$. cereus cells in dairy products.

Key words: Bacillus cereus vegetative cells, olive oil polyphenol extract, raw milk, antibacterial effect

\section{INTRODUCTION}

Bacillus cereus, a gram-positive endospore-forming bacteria, is considered one of the important spoil-

Received June 9, 2018.

Accepted January 13, 2019.

*Corresponding author: guoling@neau.edu.cn age microorganisms in the dairy industry and can contaminate dairy products through the production environment (Kumari and Sarkar, 2016). This organism secretes lipase and protease, which cause loss of nutrients from dairy products and shorten shelf life (Nemeckova et al., 2009). Moreover, as a result of the production of enterotoxins and emetic toxin, B. cereus can cause emesis and diarrhea severe enough to result in hospitalization or even death (Schoeni and Wong, 2005). Several measures have been taken in the dairy industry to reduce product contamination by $B$. cereus, but cases of $B$. cereus contamination are still reported frequently (Gundogan and Avci, 2014; Alnakip, 2016; Spanu et al., 2016; Fossi et al., 2017).

Currently, thermal sterilization technology and synthetic preservatives are the most common methods to inhibit the growth of $B$. cereus strains in dairy products (Rendueles et al., 2011; Kumari and Sarkar, 2016). However, heat treatment can have many negative effects on the quality of milk and dairy products, including undesirable protein denaturation, nonenzymatic browning, loss of vitamins and volatile flavor compounds, freezing point depression, and flavor changes (Coutinho et al., 2018). Moreover, considering serious health risks, such as cancer, allergies, migraines, liver and kidney damage, birth defects, and brain damage, consumers are understandably wary about synthetic preservatives added to their food (Parke and Lewis, 1992; Demirci et al., 2008). Therefore, recent studies have focused on natural extracts as potential preservatives to inhibit microbial growth (Lacombe et al., 2010; Li et al., 2016; Cetin-Karaca and Newman, 2018). Lacombe et al. (2010) found that the sugars, organic acids, phenolics, and anthocyanins extracted from American cranberry have strong antimicrobial activity against Escherichia coli O157:H7. Li et al. (2016) reported that Cronobacter sakazakii in powdered infant formula can be reduced by tea polyphenols acidified with $4 \mathrm{~mol} / \mathrm{mL}$ of hydrochloric acid $(\mathrm{pH}=3.55)$, from $7 \log \mathrm{cfu} / \mathrm{mL}$ to an undetectable level within $7 \mathrm{~h}$. Cetin-Karaca and Newman (2018) showed that phytochemicals, including trans-cinnamaldehyde, (-)-epigallocatechin gallate, 
and [10]-gingerol, can effectively inhibit the growth of $B$. cereus in reconstituted infant rice.

Olive oil polyphenol extract (OOPE), composed of polyphenols, hydroxytyrosol, tyrosol, and phenolic acids, has attracted much attention on account of its antioxidant properties, which are considered to be the main reason that natural extracts can inhibit the growth of pathogenic microorganisms (Visioli et al., 1998; Gordon et al., 2001; O'Dowd et al., 2004; Gupta et al., 2012). As an example, tea polyphenols or tea extracts with antioxidant capacity have been confirmed to have significant antimicrobial activity against Staphylococcus aureus, Salmonella Enteritidis, Serratia marcescens, B. cereus, and C. sakazakii (Friedman et al., 2006; Lacombe et al., 2010; Yi et al., 2014; Zhang et al., 2014). Therefore, enough evidence exists to show OOPE as a potential preservative to inactivate the growth of $B$. cereus (Fei et al., 2018; Yakhlef et al., 2018). However, few reports have been published on the antimicrobial activity and mechanism of action of OOPE against $B$. cereus strains.

The aim of our study was to analyze the antimicrobial activity of OOPE against vegetative cells of $B$. cereus strains isolated from raw milk and clarify the possible mechanism of action. The diameter of inhibition zone (DIZ), MIC, and minimum bactericidal concentration (MBC) were determined to evaluate the antibacterial effect of OOPE against $B$. cereus cells. The reduction of viable $B$. cereus cell counts after treatment with OOPE in sterile normal saline (NS) and pasteurized milk (PM) were measured to assess the antibacterial ability in the medium with and without milk. The changes in intracellular ATP concentration, membrane integrity, cell morphology, and cell membrane potential were determined to explore a possible mechanism of action.

\section{MATERIALS AND METHODS}

\section{OOPE Material}

The OOPE used in our study was provided by Shanghai Kai Da Biotechnology Co. Ltd. (Shanghai, China). The polyphenols were extracted from olive oil using a supercritical fluid extraction, and dried into powder with a vacuum freeze-drying method. The final moisture of the OOPE was less than $7 \%$. Detailed chemical composition of the compound is shown in Table 1.

\section{Bacteria and Culture Conditions}

Ten $B$. cereus strains were used in our study. One of these strains, B. cereus ATCC 14579, was obtained from American Type Culture Collection (ATCC, Manassas,
VA). The other 9 were isolated from different raw milk samples, identified using $16 \mathrm{~S}$ rDNA sequencing by our team, and named GF-1, GF-2, GF-3, GF-4, GF-5, GF-6, GF-7, GF-8, and GF-9, respectively. One hundred microliters of cultures were transferred to $10 \mathrm{~mL}$ of brain heart infusion (BHI) broth, and incubated at $30^{\circ} \mathrm{C}$ for $24 \mathrm{~h}$. The cultures were streaked onto mannitol egg yolk polymyxin (MEYP) agar plates, adding mycosin B and yolk emulsion, and incubated at $30^{\circ} \mathrm{C}$ for $20 \mathrm{~h}$. A typical colony was selected and incubated in BHI broth at $30^{\circ} \mathrm{C}$ for $24 \mathrm{~h}$ to obtain the pure culture of $B$. cereus strains.

\section{Disk Diffusion Assay}

The antimicrobial effect of OOPE against B. cereus cells was evaluated using the disk diffusion method with minor modification (Barry and Barry, 1976). One hundred microliters of bacterial suspension $\left(10^{6} \mathrm{cfu} / \mathrm{mL}\right)$ was spread evenly on the BHI agar. Fifteen microliters of OOPE $(10 \mathrm{mg} / \mathrm{mL})$ was added to filter paper disks (6 mm diameter), placed on the BHI agar inoculated with B. cereus strains, and incubated at $30^{\circ} \mathrm{C}$ for $24 \mathrm{~h}$. Each treatment was performed with 3 replications. An equal part of the sterilized distilled water was used as a negative control. The DIZ was measured to evaluate the antibacterial effect of OOPE.

\section{Determinations of MIC and MBC}

The MIC values of OOPE for $10 \mathrm{~B}$. cereus strains were determined using the agar dilution method as described by the European Committee for Antimicrobial Susceptibility Testing of the European Society of Clinical Microbiology and Infectious Dieases (2000). The OOPE was mixed with warm (about $50^{\circ} \mathrm{C}$ ) MEYP agar in the sterile 24-well plates. The final concentrations of OOPE were adjusted to $0,0.3125,0.625,1.25$, 2.5 , and $5 \mathrm{mg} / \mathrm{mL}$, respectively, the mixture in wells was mixed by gentle blowing, and $0.1 \mathrm{mg} / \mathrm{mL}$ of ampicillin was used as positive control. Two microliters of B. cereus culture $\left(10^{6} \mathrm{cfu} / \mathrm{mL}\right)$ was inoculated on the solidified MEYP agar. After the cultures were dried,

Table 1. Chemical composition of olive oil polyphenol extract (OOPE) used in this study

\begin{tabular}{lc}
\hline Composition & Content $(\%, w t / w t)$ \\
\hline Total polyphenols & $\geq 30$ \\
Hydroxytyrosol & $\geq 6$ \\
Tyrosol & $\geq 0.8$ \\
Phenolic acids & $\geq 1.5$ \\
Residual solvent content & $<0.1$ \\
Ethanol & \\
\hline
\end{tabular}


the 24-well plates were incubated at $30^{\circ} \mathrm{C}$ for $24 \mathrm{~h}$. The MIC of OOPE against B. cereus is defined as the lowest concentration at which test organisms cannot grow on MEYP agar. After the MIC of OOPE against each strain was determined, $100 \mu \mathrm{L}$ of culture was treated with $\geq 1$ MIC of OOPE and spread on the MEYP plates, followed by incubation at $30^{\circ} \mathrm{C}$ for $24 \mathrm{~h}$. The lowest concentration of OOPE that causes the absence of colonies was identified as the MBC of OOPE against $B$. cereus vegetative cells.

\section{Reduction of B. cereus GF-1 by OOPE in NS and PM}

Two milliliters of $B$. cereus GF-1 culture was centrifuged at $8,000 \times g$ for $10 \mathrm{~min}$ at $4^{\circ} \mathrm{C}$ to obtain the working cell pellets and stored at $4^{\circ} \mathrm{C}$ for further study. The pellets were transferred in $1 \mathrm{~mL}$ of sterile NS and colonies were enumerated on MEYP plates after gradient dilution. The density of the working culture was then adjusted to $10^{8} \mathrm{cfu} / \mathrm{mL}$ with sterile NS and $10^{6} \mathrm{cfu} / \mathrm{mL}$ with PM. The OOPE was added to the working cultures to obtain the final concentrations of $0,0.5,1,1.5$, and 2 MIC. Samples treated with OOPE in NS were incubated at $30^{\circ} \mathrm{C}$ for $0.5,1,3$, and $5 \mathrm{~h}$. Meanwhile, samples treated with OOPE in PM were incubated at $30^{\circ} \mathrm{C}$ for $2,4,6,8$, and $10 \mathrm{~h}$. One hundred microliters of each sample after different treatments was spread on MEYP plates in triplicate to calculate survival populations of $B$. cereus GF-1 cells.

\section{Measurement of Intracellular ATP Concentrations}

The intracellular ATP concentrations of $B$. cereus GF-1 cells with different treatments were measured according to the method described by Sánchez et al. (2010) and Shi et al. (2016c). The OOPE was added to $2 \mathrm{~mL}$ of bacterial suspension $\left(10^{7} \mathrm{cfu} / \mathrm{mL}\right)$ to achieve final concentrations of 0,1 , and 2 MIC. The mixtures were incubated at $30^{\circ} \mathrm{C}$ for $30 \mathrm{~min}$ followed by disintegration using ultrasonic treatment, then kept at $100^{\circ} \mathrm{C}$ for 2 to $3 \mathrm{~min}$ to inactivate the ATPase. To obtain the supernatants, the samples were centrifuged at 5,000 $\times$ $g$ for 5 min at $0^{\circ} \mathrm{C}$ using a high-speed freezing centrifuge (Shanghai Centrifuge Institute Co. Ltd., Shanghai, China). Finally, the supernatants were added to the white 96-well microtiter plates to determine the intracellular ATP concentrations of samples using an ATP assay kit (Beyotime Bioengineering Institute, Shanghai, China).

\section{Determination of Membrane Potential}

The effect of OOPE on membrane potential of $B$. cereus GF-1 cells was analyzed as described by previous reports (Sánchez et al., 2010; Shi et al., 2016c).
One hundred microliters of bacterial suspension $\left(10^{7}\right.$ $\mathrm{cfu} / \mathrm{mL}$ ) was added to black 96 -well microtiter plates and incubated at $30^{\circ} \mathrm{C}$ for $30 \mathrm{~min}$. The OOPE was mixed in the bacterial suspension to obtain the final concentrations of 0,1 , and $2 \mathrm{MIC}$, followed by incubation at $30^{\circ} \mathrm{C}$ for 30 min. Bis-(1, 3-dibutylbarbituric acid) trimethine oxonol [DiBAC4 (3), Beijing Solarbio Sciences and Technology Co. Ltd., Beijing, China] was used as membrane potential-sensitive fluorescent probe. Fluorescence was measured at excitation and emission wavelengths of 492 and $515 \mathrm{~nm}$, respectively, according to the manufacturer's instructions (Fei et al., 2018).

\section{SDS-PAGE}

Bacterial proteins of $B$. cereus GF-1 cells were analyzed using SDS-PAGE according to Bradford (1976). Approximately $10^{7} \mathrm{cfu} / \mathrm{mL}$ of $B$. cereus GF-1 cells were treated with $1 \mathrm{MIC}$ of $\mathrm{OOPE}$ at $30^{\circ} \mathrm{C}$ for $3,6,9$, and $12 \mathrm{~h}$. The supernatants were prepared by centrifugation at $8,000 \times g$ at $4^{\circ} \mathrm{C}$ for $10 \mathrm{~min}$ and mixed with SDS-PAGE loading buffer. The samples were heated at $95^{\circ} \mathrm{C}$ for $10 \mathrm{~min}$ and analyzed by SDS-PAGE using a $5 \%$ stacking gel and a $15 \%$ separating gel. The protein bands were stained with Coomassie brilliant blue R-250 (Beijing Solarbio Sciences and Technology Co. Ltd.) in the gel, and scanned with an HP scanner (HP 1000, Hewlett-Packard Co. Ltd., Beijing, China). As a negative control, untreated $B$. cereus cells were analyzed with the same processing.

\section{Transmission Electron Microscopy Analysis}

According to previous studies, transmission electron microscope was used to observe the cell morphology of B. cereus GF-1 cells after treatments with OOPE at 0 , 1, and 2 MIC for $4 \mathrm{~h}$ (Karlsson et al., 2007; Li et al., 2016). The cultures were centrifuged at $3,000 \times g$ for 5 min at $4^{\circ} \mathrm{C}$ to prepare the working cells. The cells were fixed using $0.1 \mathrm{M}$ sodium phosphate buffer $(2.5 \%$ glutaraldehyde) at $4^{\circ} \mathrm{C}$ for $12 \mathrm{~h}$, and washed 3 times with NS. They were further fixed in $1 \%$ osmium tetroxide at $4^{\circ} \mathrm{C}$ for $2 \mathrm{~h}$ followed by washing 3 times with NS. The cells were dehydrated with a graded series of ethanol (50, 70, 90, and 100\%) for $10 \mathrm{~min}$, and embedded in Epon Lx-112 (Ladd Research, Williston, VT), followed by double staining with uranyl acetate and lead citrate. Finally, all samples were observed under the transmission electron microscope (Hitachi, Tokyo, Japan).

\section{Statistical Analysis}

Five experiments, including disk diffusion assay, determinations of MIC and MBC, reduction of B. ce- 
reus GF-1 by OOPE in NS and PM, measurement of intracellular ATP concentrations, and determinations of membrane potential, were carried out in triplicate. Statistical analyses were performed by ANOVA using the SPSS 20.0 software (IBM Corp., Armonk, NY). The data were expressed as mean values \pm standard deviations. Significant differences $(P<0.05)$ between treatments were determined using Tukey's multiple range test.

\section{RESULTS}

\section{Antimicrobial Effects of OOPE on B. cereus Strains}

The OOPE showed satisfactory antimicrobial effects against vegetative cells of 10 strains, as shown in Table 2. The mean DIZ of OOPE against the 10 strains was $18.44 \pm 0.55 \mathrm{~mm}$. No significant differences $(P>0.05)$ in DIZ values of OOPE against $B$. cereus strains were found. The MIC and MBC of OOPE against the 10 strains were 0.625 and $1.25 \mathrm{mg} / \mathrm{mL}$, respectively. We found no significant difference in the antibacterial effect of OOPE against $10 \mathrm{~B}$. cereus isolates. Considering that it is of more practical significance to determine the antibacterial mechanism of OOPE using $B$. cereus strains isolated from raw milk, B. cereus GF-1 was randomly chosen for future studies.

\section{Reduction of B. cereus GF-1 by OOPE}

The antimicrobial effects of OOPE against $B$. cereus GF-1 cells in NS and PM were evaluated and are shown in Figure 1. Compared with the control group, the growth of $B$. cereus GF-1 cells in NS and PM was significantly inhibited by treatments with 1 and $2 \mathrm{MIC}$ of OOPE $(P<0.05)$. Furthermore, the concentration of
B. cereus cells was reduced to 0 from 8 and $6 \log \mathrm{cfu} /$ $\mathrm{mL}$, respectively, with $2 \mathrm{MIC}(1.25 \mathrm{mg} / \mathrm{mL})$ of OOPE in NS after $0.5 \mathrm{~h}$ or in PM after $6 \mathrm{~h}$.

\section{Changes in Intracellular ATP Concentrations}

Figure 2 shows that, compared with those of control group, the intracellular ATP concentrations of $B$. cereus GF-1 cells treated with OOPE at 1 and 2 MIC for $0.5 \mathrm{~h}$ were significantly reduced $(P<0.05)$. In addition, with the increase of OOPE concentrations, the concentrations of intracellular ATP of tested cells were significantly decreased $(P<0.05)$.

\section{Changes in Membrane Potential}

As shown in Figure 3, the fluorescence of B. cereus GF-1 cells treated with OOPE was compared with that of untreated cells. The result indicated that, compared with control group, a significant increase in fluorescence occurred in the cells treated with 1 and $2 \mathrm{MIC}$ of OOPE $(P<0.05)$, which suggested that OOPE led to the cell membrane depolarization of $B$. cereus GF-1 cells.

\section{SDS-PAGE Analysis}

The bacterial protein of $B$. cereus GF-1 cells treated with 1 MIC of OOPE was compared with that of untreated cells using SDS-PAGE analysis (Figure 4). The result showed that protein bands of $B$. cereus GF-1 cells treated with 1 MIC of OOPE were fainter compared with control protein bands. Furthermore, after a treatment with 1 MIC of OOPE for more than $6 \mathrm{~h}$, almost all protein bands disappeared.

Table 2. Antimicrobial activity of olive oil polyphenol extract (OOPE) against all 10 Bacillus cereus strains

\begin{tabular}{llccc}
\hline Strain & Source & $\begin{array}{c}\text { Diameter } \\
\text { of inhibition } \\
\text { zone }(\mathrm{mm})\end{array}$ & $\begin{array}{c}\text { MIC } \\
(\mathrm{mg} / \mathrm{mL})\end{array}$ & $\begin{array}{c}\text { Minimum } \\
\text { bactericidal concentration } \\
(\mathrm{mg} / \mathrm{mL})\end{array}$ \\
\hline ATCC 14579 & $\begin{array}{l}\text { American Type Culture Collection } \\
\text { (Manassas, VA) }\end{array}$ & $18.34 \pm 0.55^{\mathrm{a}}$ & 0.625 & 1.25 \\
GF-1 & Raw milk & $18.26 \pm 0.48^{\mathrm{a}}$ & 0.625 & 1.25 \\
GF-2 & Raw milk & $18.54 \pm 0.57^{\mathrm{a}}$ & 0.625 & 1.25 \\
GF-3 & Raw milk & $18.41 \pm 0.45^{\mathrm{a}}$ & 0.625 & 1.25 \\
GF-4 & Raw milk & $18.28 \pm 0.47^{\mathrm{a}}$ & 0.625 & 1.25 \\
GF-5 & Raw milk & $18.32 \pm 0.40^{\mathrm{a}}$ & 0.625 & 1.25 \\
GF-6 & Raw milk & $18.29 \pm 0.65^{\mathrm{a}}$ & 0.625 & 1.25 \\
GF-7 & Raw milk & $18.56 \pm 0.53^{\mathrm{a}}$ & 0.625 & 1.25 \\
GF-8 & Raw milk & $18.43 \pm 0.42^{\mathrm{a}}$ & 0.625 & 1.25 \\
Co & & $18.50 \pm 0.47^{\mathrm{a}}$ & 0.625 & \\
\hline
\end{tabular}

${ }^{\mathrm{a}}$ Column values with the same letter are not significantly different $(P<0.05)$. 
Transmission Electron Microscope Observation

As compared with the regular morphology of $B$. cereus GF-1 cells (Figure 5A), the cells treated with
OOPE displayed serious deformation and cytoplasmic leakage (Figure 5B and C). Furthermore, the degree of cell deformation and cytoplasmic leakage increased as the concentration of OOPE increased.

\section{MIC $60.5 \mathrm{MIC} \otimes 1 \mathrm{MIC}$ 四 $1.5 \mathrm{MIC}$ 远 $2 \mathrm{MIC}$}
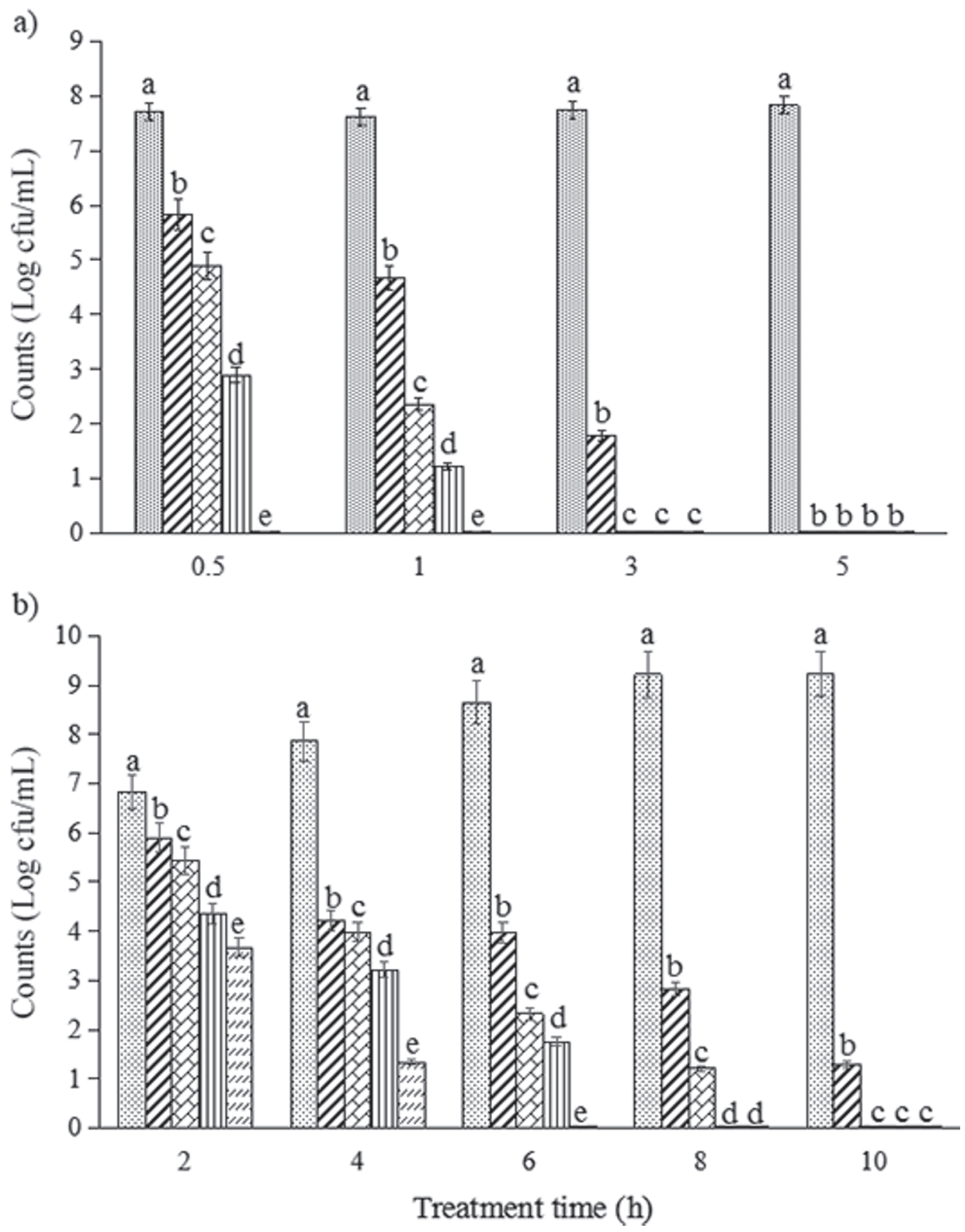

Figure 1. Reduction of Bacillus cereus GF-1 vegetative cells after treatment with different concentrations of olive oil polyphenols extract (OOPE) in normal saline (A) and pasteurized milk (B). Error bars denote SD. Different letters (a-e) denote significant differences between treatments within the same incubation time points $(P<0.05)$. 


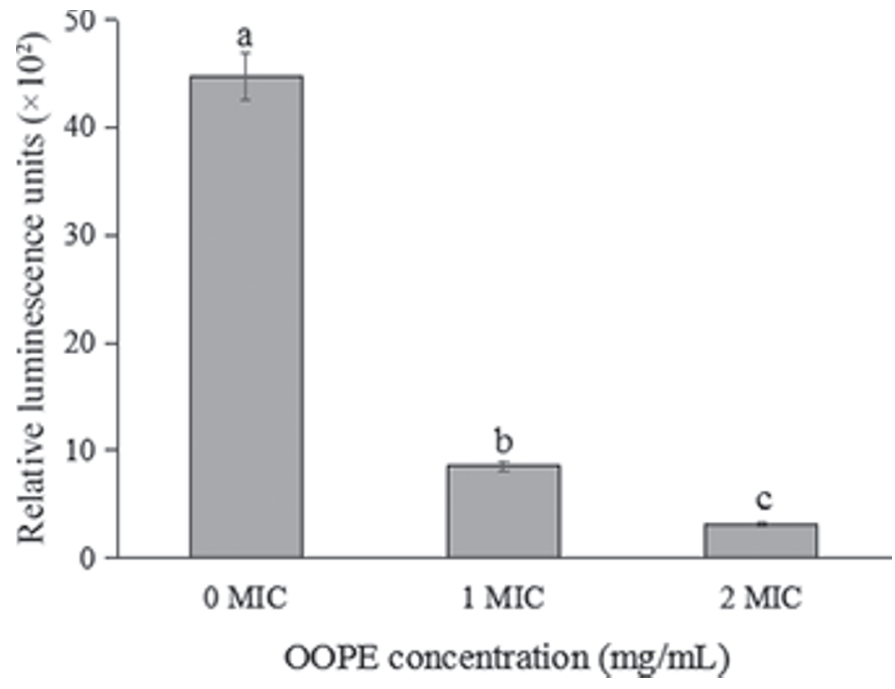

Figure 2. Change in intracellular ATP concentrations of Bacillus cereus GF-1 vegetative cells after treatments with 0,1 , and 2 MIC of olive oil polyphenol extract (OOPE). Values represent the means of independent triplicate measurements. Bars represent the SD $(\mathrm{n}=3)$. Different letters $(\mathrm{a}-\mathrm{c})$ denote significant differences $(P<0.05)$.

\section{DISCUSSION}

Many studies have focused on the antimicrobial effects of natural extracts on food-borne pathogens, and some natural ingredients have been reported to inhibit the growth of $B$. cereus strains (Ultee et al., 2002; Valero and Salmeron, 2003; Ponce et al., 2008; Cetin-Karaca and Newman, 2018). Valero and Salmeron (2003) showed that the growth of B. cereus in refrigerated processed food products was inhibited for

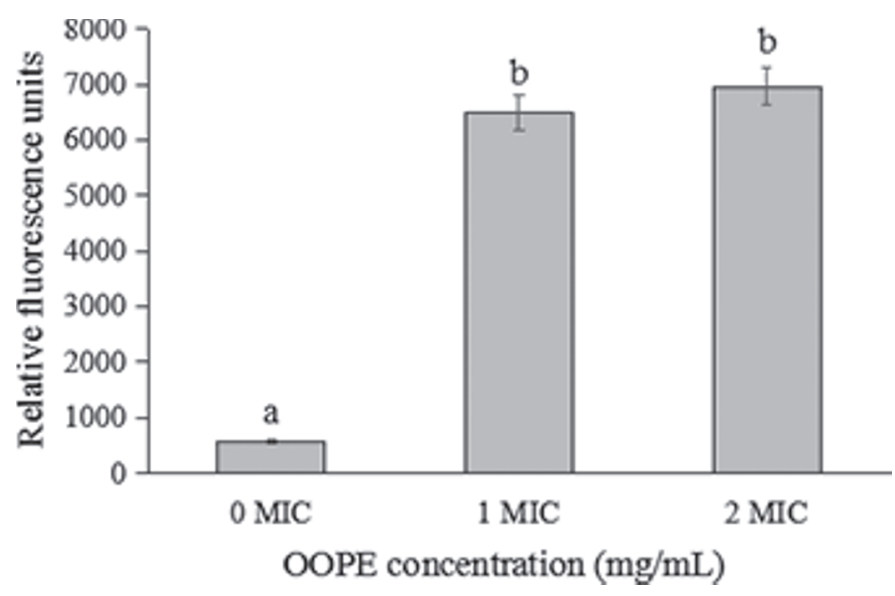

Figure 3. Change in membrane potentials (measured as relative fluorescence units) of Bacillus cereus GF-1 vegetative cells following treatments with 0,1 , and 2 MIC of olive oil polyphenol extract (OOPE). Values represent the means of independent triplicate measurements. Bars represent the SD $(\mathrm{n}=3)$. Different letters $(\mathrm{a}, \mathrm{b})$ denote significant differences $(P<0.05)$. at least $60 \mathrm{~d}$ by adding $5 \mu \mathrm{L} / 100 \mathrm{~mL}$ of cinnamon essential oil at $\leq 8^{\circ} \mathrm{C}$. Cetin-Karaca and Newman (2018) reported that $0.83 \log \mathrm{cfu} / \mathrm{g} B$. cereus cells and 2.0 $\log \mathrm{cfu} / \mathrm{g}$ of $B$. cereus spores in reconstituted infant rice cereal decreased after a treatment with $0.05 \%$ of trans-cinnamaldehyde at $37^{\circ} \mathrm{C}$ for $24 \mathrm{~h}$. In addition, tea extracts and phenolic hydroxyl groups of carvacrol were also used to inhibit growth of B. cereus (Ultee et al., 2002; Friedman et al., 2006).

Bacillus cereus has been reported to be one of the most common pathogenic microorganisms contaminating the dairy processing environment (Brandl et al., 2014). Once dairy products are contaminated with $B$. cereus, it can cause serious food-borne disease outbreaks and accelerate the spoilage of dairy products (Bedi et al., 2005; Chitov et al., 2008; Kumari and Sarkar, 2016). In addition, this pathogen secretes protease and lipase, which can cause nutritional loss and a decrease in sensory properties of dairy products (Kumari and Sarkar, 2016). Therefore, it is necessary to analyze the antibacterial effect of OOPE against $B$. cereus in dairy products. Our findings indicated that approximately 6 $\log \mathrm{cfu} / \mathrm{mL}$ of $B$. cereus cells in PM were reduced to 0 $\log \mathrm{cfu} / \mathrm{mL}$ after treatment with OOPE at $30^{\circ} \mathrm{C}$ for $6 \mathrm{~h}$. This indicates that OOPE is a viable natural antibacterial substance for treating dairy products. A similar study ( $\mathrm{Li}$ et al., 2016) evaluated the antimicrobial activity of acidified tea polyphenols against $C$. sakazakii in rehydrated powdered infant formula. In comparison with tea polyphenols, OOPE consists of more active substances, including phenolic acids, hydroxytyrosol, and tyrosol, which have been confirmed as the major components of OOPE with antibacterial effects (Gordon et al., 2001; O'Dowd et al., 2004; Cruz-Romero et al., 2013; Zhu et al., 2013).

In previous studies, the intracellular ATP concentration was analyzed as a primary consideration, because ATP provides energy for normal physiological activities in microorganisms (Shi et al., 2016a,b,c). In the current study, we found that intracellular ATP concentration of $B$. cereus GF-1 decreased significantly after treatment with OOPE as compared with control cells. The decrease of intracellular ATP concentration has been associated with leakage of intracellular ATP, depletion of the intracellular ATP pool, and dissipation of proton motive force components (Gill and Holley, 2004). Therefore, in conjunction with transmission electron microscopy results (Figure 5), our results suggest the reduction of $B$. cereus GF-1 cells might be related to the loss of ATP during destruction of cell membrane integrity, especially considering that similar results were found in the action of inhibiting C. sakazakii by lipoic acid, citral, and syringic acid, respectively (Shi et al., 2016a,b,c). 


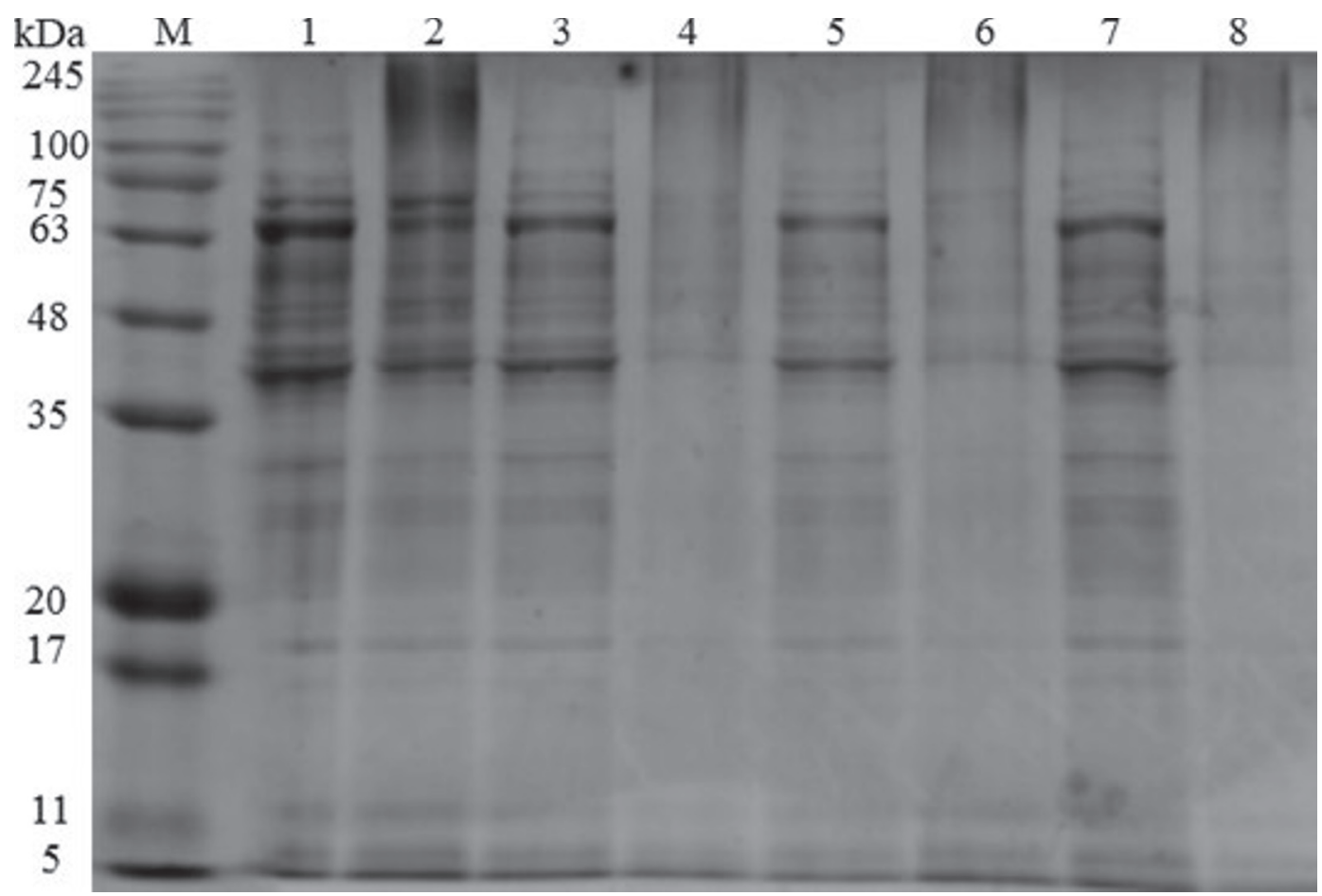

Figure 4. Sodium dodecyl sulfate-PAGE analysis of proteins of Bacillus cereus GF-1 vegetative cells treated with 1 MIC of olive oil polyphenol extract (OOPE). Lane $\mathrm{M}=$ marker; lanes $1,3,5,7=$ control for $3,6,9$, and 12 h respectively; lanes $2,4,6,8=$ treated samples for 3 , 6,9 , and $12 \mathrm{~h}$, respectively.

Change of membrane potential is considered a factor in the natural extract antibacterial process due to its important role in cell antibiotic uptake and bactericidal action (Bot and Prodan, 2009). Our finding showed that OOPE caused membrane depolarization of $B$. cereus GF-1 cells, which is an important type of membrane damage associated with a less negative charge inside the cell (Gries et al., 2013). Similarly, Vibrio cholerae cells, after exposure to nopal cactus methanolic extracts, and C. sakazakii cells treated with lipoic acid also resulted in cell membrane depolarization (Sánchez et al., 2010; Shi et al., 2016b).

To further reveal the mechanism of action of OOPE against B. cereus cell, SDS-PAGE was used to analyze the change in protein levels in supernatants of tested strains after treatment with OOPE. Bacterial protein, as the basic OM of cells, is closely related to bacterial life activities and important physiological functions (Wang et al., 2015). Our findings showed that a significant reduction of protein was found in super-
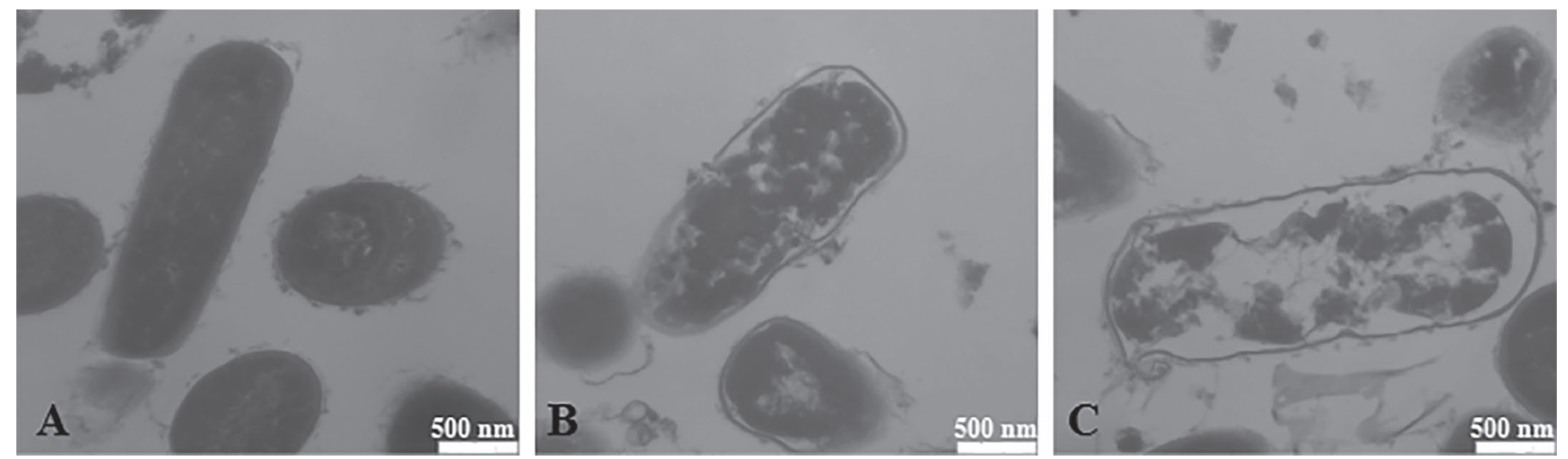

Figure 5. Transmission electron microscopy images of Bacillus cereus GF-1 vegetative cells $(40,000 \times)$ untreated for $4 \mathrm{~h}(\mathrm{~A})$, treated with 1 MIC of olive oil polyphenol extract (OOPE) for $4 \mathrm{~h}$ (B), or treated with 2 MIC of OOPE for $4 \mathrm{~h}(\mathrm{C})$. 
natant of B. cereus GF-1 cells, and all protein bands disappeared after treatment with OOPE for $6 \mathrm{~h}$. These results suggest that the proteins leaked out of the cells due to loss of membrane integrity, as shown by the micrographs (Figure 5). This is similar to the results of sugarcane bagasse extract against Staph. aureus, sugar beet molasses polyphenols against Staph. aureus, Listeria monocytogenes, Escherichia coli, and Salmonella Typhimurium (Zhao et al., 2015; Chen et al., 2017).

Cellular morphology of bacteria under electron microscopy can reflect the state of bacteria under the stimulation of natural products (Joshi et al., 2014; $\mathrm{Xu}$ et al., 2017). Joshi et al. (2014) found that, after treatments with blueberry proanthocyanidin and commercial blueberry juice, pores and bubbles were observed on the cell surface of $C$. sakazakii strains under a scanning electron microscope. The study reported by $\mathrm{Xu}$ et al. (2017) showed that compared with untreated cells, the Staph. aureus cells treated with punicalagin became larger and had a rough surface. The antibacterial process of tea polyphenols caused serious cell deformation and cytoplasmic leakage in C. sakazakii, and American cranberry extract had a similar effect against E. coli O157:H7 (Lacombe et al., 2010; Li et al., 2016). Similarly, the cell morphology of $B$. cereus was obviously damaged after treatment with OOPE due to the leakage of cytoplasm caused by increased permeability of the cell membrane.

\section{CONCLUSIONS}

In general, OOPE had a significant antibacterial effect against vegetative cells of $B$. cereus strains isolated from raw milk. The antimicrobial mechanism of OOPE may be due to the reduction of intracellular ATP levels, cell membrane depolarization, a decrease in cellular protein, and cytoplasm leakage. Our findings indicated that OOPE can be considered as a natural food additive to prevent $B$. cereus contamination in the dairy industry. However, before adding OOPE to dairy products as a bactericidal substance, further studies, including safety experiments, dosage optimization, and analysis of the sensory characteristics of foods, should be considered.

\section{ACKNOWLEDGMENTS}

This study was supported by the Open Research Fund for Key Laboratory of Dairy Science, Ministry of Education, Heilongjiang Province, China (2017KLDS06), Key Scientific and Technological Project of Henan Province, Henan Province, China (161100110900), and Doctor Scientific Research Start-up Fund of Henan
University of Science and Technology, Luoyang, China (13480066).

\section{REFERENCES}

Alnakip, M. E. A. 2016. Occurrence of Bacillus cereus in raw milk and some dairy products in Egypt. Jpn. J. Vet. Res. 64:S95-S102.

Barry, L. A., and A. L. Barry. 1976. The Antimicrobic Susceptibility Test: Principles and Practices. Lea \& Febiger, New York, NY.

Bedi, S. K., C. S. Sharma, J. P. S. Gill, R. S. Aulakh, and J. K. Sharma. 2005. Incidence of enterotoxigenic Bacillus cereus in milk and milk products. J. Food. Sci. Technol. Mysore 42:272-275.

Bot, C., and C. Prodan. 2009. Probing the membrane potential of living cells by dielectric spectroscopy. Eur. Biophys. J. 38:1049-1059.

Bradford, M. M. 1976. A rapid and sensitive method for the quantitation of microgram quantities of protein utilizing the principle of protein-dye binding. Anal. Biochem. 72:248-254.

Brandl, H., C. Fricker-Feer, D. Ziegler, J. Mandal, R. Stephan, and A. Lehner. 2014. Distribution and identification of culturable airborne microorganisms in a Swiss milk processing facility. J. Dairy Sci. 97:240-246.

Cetin-Karaca, H., and M. C. Newman. 2018. Antimicrobial efficacy of phytochemicals against Bacillus cereus in reconstituted infant rice cereal. Food Microbiol. 69:189-195.

Chen, M. S., Z. G. Zhao, H. C. Meng, and S. J. Yu. 2017. Antibiotic activity and mechanisms of sugar beet (Beta vulgaris) molasses polyphenols against selected food-borne pathogens. Lebensm. Wiss. Technol. 82:354-360.

Chitov, T., R. Dispan, and W. Kasinrerk. 2008. Incidence and diarrhegenic potential of Bacillus cereus in pasteurized milk and cereal products in Thailand. J. Food Saf. 28:467-481.

Coutinho, N. M., M. R. Silveira, R. S. Rocha, J. Moraes, M. V. S. Ferreira, T. C. Pimentel, M. Q. Freitas, M. C. Silva, R. S. L. Raices, C. S. Ranadheera, F. O. Borges, S. P. Mathias, F. A. N. Fernandes, S. Rodrigues, and A. G. Cruz. 2018. Cold plasma processing of milk and dairy products. Trends Food Sci. Technol. 74:56-68.

Cruz-Romero, M. C., T. Murphy, M. Morris, E. Cummins, and J. P. Kerry. 2013. Antimicrobial activity of chitosan, organic acids and nano-sized solubilisates for potential use in smart antimicrobially active packaging for potential food applications. Food Control 34:393-397.

Demirci, F., K. Guven, B. Demirci, M. Y. Dadandi, and K. H. C. Baser. 2008. Antibacterial activity of two Phlomis essential oils against food pathogens. Food Control 19:1159-1164.

European Committee for Antimicrobial Susceptibility Testing (EUCAST) of the European Society of Clinical Microbiology and Infectious Dieases (ESCMID). 2000. Determination of minimum inhibitory concentrations (MICs) of antibacterial agents by agar dilution. Clin. Microbiol. Infect. 6:509-515.

Fei, P., M. A. Ali, S. Y. Gong, Q. Sun, X. Bi, S. F. Liu, and L. Guo. 2018. Antimicrobial activity and mechanism of action of olive oil polyphenols extract against Cronobacter sakazakii. Food Control 94:289-294.

Fossi, B. T., J. Akoachere, G. T. Nchanji, and S. Wanji. 2017. Occurrence, heat and antibiotic resistance profile of Bacillus cereus isolated from raw cow and processed milk in Mezam Division, Cameroon. Int. J. Dairy Technol. 70:43-51.

Friedman, M., P. R. Henika, C. E. Levin, R. E. Mandrell, and N. Kozukue. 2006. Antimicrobial activities of tea catechins and theaflavins and tea extracts against Bacillus cereus. J. Food Prot. 69:354-361.

Gill, A. O., and R. A. Holley. 2004. Mechanisms of bactericidal action of cinnamaldehyde against Listeria monocytogenes and of eugenol against L. monocytogenes and Lactobacillus sakei. Appl. Environ. Microbiol. 70:5750-5755.

Gordon, M. H., F. Paiva-Martins, and M. Almeida. 2001. Antioxidant activity of hydroxytyrosol acetate compared with that of other olive oil polyphenols. J. Agric. Food Chem. 49:2480-2485.

Gries, C. M., J. L. Bose, A. S. Nuxoll, P. D. Fey, and K. W. Bayles. 2013. The Ktr potassium transport system in Staphylococcus au- 
reus and its role in cell physiology, antimicrobial resistance and pathogenesis. Mol. Microbiol. 89:760-773.

Gundogan, N., and E. Avci. 2014. Occurrence and antibiotic resistance of Escherichia coli, Staphylococcus aureus and Bacillus cereus in raw milk and dairy products in Turkey. Int. J. Dairy Technol. $67: 562-569$.

Gupta, S., S. Cox, G. Rajauria, A. K. Jaiswal, and N. Abu-Ghannam. 2012. Growth inhibition of common food spoilage and pathogenic microorganisms in the presence of brown seaweed extracts. Food Bioprocess Technol. 5:1907-1916.

Joshi, S. S., A. B. Howell, and D. H. D'Souza. 2014. Cronobacter sakazakii reduction by blueberry proanthocyanidins. Food Microbiol. $39: 127-131$.

Karlsson, A., R. Ipsen, and Y. Ardo. 2007. Observations of casein micelles in skim milk concentrate by transmission electron microscopy. Lebensm. Wiss. Technol. 40:1102-1107.

Kumari, S., and P. K. Sarkar. 2016. Bacillus cereus hazard and control in industrial dairy processing environment. Food Control 69:20-29.

Lacombe, A., V. C. H. Wu, S. Tyler, and K. Edwards. 2010. Antimicrobial action of the American cranberry constituents; phenolics, anthocyanins, and organic acids, against Escherichia coli O157:H7. Int. J. Food Microbiol. 139:102-107.

Li, R., P. Fei, C. X. Man, B. B. Lou, J. T. Niu, J. Feng, L. H. Sun, M. Y. Li, and Y. J. Jiang. 2016. Tea polyphenols inactivate Cronobacter sakazakii isolated from powdered infant formula. J. Dairy Sci. 99:1019-1028.

Nemeckova, I., M. Pechacova, and P. Roubal. 2009. Problems with detection of proteolytic microorganisms and their undesirable activities in milk. Czech J. Food Sci. 27:82-89.

O'Dowd, Y., F. Driss, P. M. Dang, C. Elbim, M. A. Gougerot-Pocidalo, C. Pasquier, and J. El-Benna. 2004. Antioxidant effect of hydroxytyrosol, a polyphenol from olive oil: Scavenging of hydrogen peroxide but not superoxide anion produced by human neutrophils. Biochem. Pharmacol. 68:2003-2008.

Parke, D. V., and D. F. V. Lewis. 1992. Safety aspects of food preservatives. Food Addit. Contam. 9:561-577.

Ponce, A. G., S. I. Roura, C. E. del Valle, and M. R. Moreira. 2008. Antimicrobial and antioxidant activities of edible coatings enriched with natural plant extracts: In vitro and in vivo studies. Postharvest Biol. Technol. 49:294-300.

Rendueles, E., M. K. Omer, O. Alvseike, C. Alonso-Calleja, R. Capita and M. Prieto. 2011. Microbiological food safety assessment of high hydrostatic pressure processing: A review. Lebensm. Wiss. Technol. 44:1251-1260.

Sánchez, E., S. Garcia, and N. Heredia. 2010. Extracts of edible and medicinal plants damage membranes of Vibrio cholerae. Appl. Environ. Microbiol. 76:6888-6894.

Schoeni, J. L., and A. C. Wong. 2005. Bacillus cereus food poisoning and its toxins. J. Food Prot. 68:636-648.

Shi, C., K. K. Song, X. R. Zhang, Y. Sun, Y. Sui, Y. F. Chen, Z. Y. Jia, H. H. Sun, Z. Sun, and X. D. Xia. 2016a. Antimicrobial activity and possible mechanism of action of citral against Cronobacter sakazakii. PLoS One 11:e0159006.
Shi, C., Y. Sun, X. R. Zhang, Z. W. Zheng, M. C. Yang, H. Ben, K. K. Song, Y. F. Cao, Y. F. Chen, X. Liu, R. Dong, and X. D. Xia. 2016b. Antimicrobial effect of lipoic acid against Cronobacter sakazakii. Food Control 59:352-358.

Shi, C., Y. Sun, Z. W. Zheng, X. R. Zhang, K. K. Song, Z. Y. Jia, Y. F. Chen, M. C. Yang, X. Liu, R. Dong, and X. D. Xia. 2016c. Antimicrobial activity of syringic acid against Cronobacter sakazakii and its effect on cell membrane. Food Chem. 197:100-106.

Spanu, C., C. Scarano, V. Spanu, C. Pala, D. Casti, S. Lamon, F. Cossu, M. Ibba, G. Nieddu, and E. P. L. De Santis. 2016. Occurrence and behavior of Bacillus cereus in naturally contaminated ricotta salata cheese during refrigerated storage. Food Microbiol. $58: 135-138$

Ultee, A., M. H. J. Bennik, and R. Moezelaar. 2002. The phenolic hydroxyl group of carvacrol is essential for action against the food-borne pathogen Bacillus cereus. Appl. Environ. Microbiol. $68: 1561-1568$.

Valero, M., and M. C. Salmeron. 2003. Antibacterial activity of 11 essential oils against Bacillus cereus in tyndallized carrot broth. Int. J. Food Microbiol. 85:73-81.

Visioli, F., G. Bellomo, and C. Galli. 1998. Free radical-scavenging properties of olive oil polyphenols. Biochem. Biophys. Res. Commun. 247:60-64.

Wang, C. J., T. Chang, H. Yang, and M. Cui. 2015. Antibacterial mechanism of lactic acid on physiological and morphological properties of Salmonella Enteritidis, Escherichia coli and Listeria monocytogenes. Food Control 47:231-236.

Xu, Y., C. Shi, Q. Wu, Z. W. Zheng, P. F. Liu, G. H. Li, X. L. Peng, and X. D. Xia. 2017. Antimicrobial activity of punicalagin against Staphylococcus aureus and its effect on biofilm formation. Foodborne Pathog. Dis. 14:282-287.

Yakhlef, W., R. Arhab, C. Romero, M. Brenes, A. de Castro, and E. Medina. 2018. Phenolic composition and antimicrobial activity of Algerian olive products and by-products. Lebensm. Wiss. Technol. 93:323-328.

Yi, S., W. Wang, F. L. Bai, J. L. Zhu, J. R. Li, X. P. Li, Y. X. Xu, T. Sun, and Y. T. He. 2014. Antimicrobial effect and membraneactive mechanism of tea polyphenols against Serratia marcescens. World J. Microbiol. Biotechnol. 30:451-460.

Zhang, H., W. Y. Zhou, W. Y. Zhang, A. L. Yang, Y. L. Liu, Y. Jiang, S. S. Huang, and J. Y. Su. 2014. Inhibitory effects of citral, cinnamaldehyde, and tea polyphenols on mixed biofilm formation by foodborne Staphylococcus aureus and Salmonella Enteritidis. J. Food Prot. 77:927-933.

Zhao, Y., M. Chen, Z. Zhao, and S. Yu. 2015. The antibiotic activity and mechanisms of sugarcane (Saccharum officinarum L.) bagasse extract against food-borne pathogens. Food Chem. 185:112-118.

Zhu, S., S. Schnell, and M. Fischer. 2013. Growth inhibition of Cronobacter spp. strains in reconstituted powdered infant formula acidified with organic acids supported by natural stomach acidity. Food Microbiol. 35:121-128. 